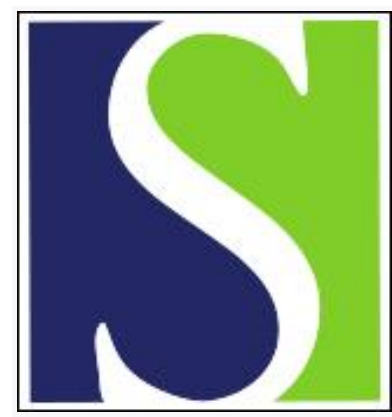

Scand J Work Environ Health 2002;28(3):184-190

https://doi.org/10.5271/sjweh.663

Issue date: Jun 2002

Physical and psychosocial prerequisites of functioning in relation to work ability and general subjective well-being among office workers

by Sjögren-Rönkä T, Ojanen MT, Leskinen EK, Mustalampi ST, Mälkiä EA

Affiliation: University of Jyväskylä, Public Health Insitute, PO Box 35, Fl-40351 Jyväskylä, Finland. tuuronka@maila.jyu.fi

Refers to the following texts of the Journal: 1997;23 suppl 1:58-65 1997;23 suppl 1:20-26 1997;23 suppl 1:49-57

The following articles refer to this text: 2007;33(5):351-357; 2009;35(1):1-5; 2010;36(5):404-412

Key terms: Disability and Health in Research; factors of work ability; International Classification of Functioning; office worker; physical prerequisite of functioning; physically light work; psychosocial prerequisite of functioning; quality of life; risk factor; subjective well-being; work ability

This article in PubMed: www.ncbi.nlm.nih.gov/pubmed/12109558

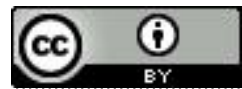




\title{
Physical and psychosocial prerequisites of functioning in relation to work ability and general subjective well-being among office workers
}

\author{
by Tuulikki Sjögren-Rönkä, MSc, ${ }^{1}$ Markku T Ojanen, PhD, ${ }^{2}$ Esko K Leskinen, PhD, ${ }^{3}$ Sirpa T Mustalampi, \\ $M S c,{ }^{4}$ Esko A Mälkiä, $P h D^{5}$
}

\begin{abstract}
Sjögren-Rönkä T, Ojanen MT, Leskinen EK, Mustalampi ST, Mälkiä EA. Physical and psychosocial prerequisites of functioning in relation to work ability and general subjective well-being among office workers. Scand J Work Environ Health 2002;28(3):184-190.
\end{abstract}

\begin{abstract}
Objectives The purpose of the study was to investigate the physical and psychological prerequisites of functioning, as well as the social environment at work and personal factors, in relation to work ability and general subjective well-being in a group of office workers.

Methods The study was a descriptive cross-sectional investigation, using path analysis, of office workers. The subjects comprised 88 volunteers, 24 men and 64 women, from the same workplace [mean age 45.7 (SD 8.6) years]. The independent variables were measured using psychosocial and physical questionnaires and physical measurements. The first dependent variable, work ability, was measured by a work ability index. The second dependent variable, general subjective well-being, was assessed by life satisfaction and meaning of life. The variables were structured according to a modified version of the International Classification of Functioning, Disability and Health.

Results Forward flexion of the spine, intensity of musculoskeletal symptoms, self-confidence, and mental stress at work explained 58\% of work ability and had indirect effects on general subjective well-being. Selfconfidence, mood, and work ability had a direct effect on general subjective well-being. The model developed explained $68 \%$ of general subjective well-being. Age played a significant role in this study population.

Conclusions The prerequisites of physical functioning are important in maintaining work ability, particularly among aging workers, and psychological prerequisites of functioning are of even greater importance in maintaining general subjective well-being.
\end{abstract}

Key terms factors of work ability, functioning, International Classification of Functioning, Disability and Health in Research, physically light work, quality of life, risk factors.

About $9 \%$ of the Finnish working-age population currently receives a disability pension, and mental disturbances and musculoskeletal diseases form the two main reasons for disability. These problems have been exacerbated by the aging of the labor force during the latter half of the past decade. Maintaining work ability and increasing the effectiveness of rehabilitation are challenges facing the health care and rehabilitation system, as well as employers $(1,2)$. Work ability is comprised of a complex of interactions involving health, the physical, psychological and social prerequisites of functioning, and personal and environmental factors.

In Finnish nonexperimental epidemiologic studies of municipal employees, associations were found between work ability and leisure-time physical activity, possibilities for development at work (3, 4), work and life

1 Department of Health Sciences, University of Jyväskylä, Jyväskylä, Finland.

2 Department of Psychology, University of Tampere, Tampere, Finland.

3 Department of Statistics, University of Jyväskylä, Jyväskylä, Finland.

4 Department of Health Sciences, University of Jyväskylä, Jyväskylä, Finland.

5 Department of Health Sciences, University of Jyväskylä, Jyväskylä, Finland.

Reprint requests to: Tuulikki Sjögren-Rönkä, University of Jyväskylä, Public Health Institute, PO Box 35, FIN-40351 Jyväskylä, Finland. [E-mail: tuuronka@maila.jyu.fi] 
satisfaction, and basic education (5). Work disability has been associated with musculoskeletal and mental symptoms, aging, being overweight, smoking (3, 5-7), and physical performance $(7,8)$. Occupational physical or social factors that impaired ability to work were poor work posture, repetitive movements, high physical demands, physically disturbing work conditions, lack of freedom, decrease in recognition and esteem at work, role ambiguity at work, and dissatisfaction with supervisor's attitude (3-6). Irrespective of diseases, work stressors and stress symptoms have shown a correlation with work ability (5). Strong intercorrelations have been found for health, life-style, work ability, and life satisfaction (9). However there is also a need for studies to explore the direct and indirect associations and causal links to work ability and well-being in different occupations.

The International Classification of Functioning, Disability and Health prompts us to consider human functioning in both the individual and social context. The "body functions" and "structure" components of this model concern the physiological and psychological prerequisites of an individual's functioning. The "activity" and "participation" components involve both individual and social perspectives. "Personal" factors refer to background factors in the individual's life, for example, age, gender, and education. Finally "environmental" factors concern the physical, social, and attitudinal environment in which people live or work. The physiological and psychological prerequisites of functioning enter into a dynamic interaction with the state of health, functioning, and personal and environmental factors. The information derived can be used as a clinical, educational, rehabilitational, and social policy tool (10).

The purpose of our study was to investigate the physical and psychological prerequisites of functioning, as well as the social environment at work and personal factors in relation to work ability and general subjective well-being in a group of office workers.

\section{Subjects and methods}

This study was a descriptive cross-sectional study of a group of office workers, and it forms part of larger experimental active rehabilitation trial. The goal of the study was to examine the effect of a physical exercise program developed to counterbalance sedentary work and to help recovery from monotonous and fixed work positions. The source population consisted of 123 local government employees from the same workplace. All the subjects' occupations were physically light, consisting mostly of mental work with a computer.
Questionnaires were sent to all members of the source population asking about their musculoskeletal symptoms, aerobic capacity, physical activity, and work ability. Those who volunteered to take part in the experimental rehabilitation study underwent further physical tests and answered psychosocial questionnaires. The final study group consisted of 88 persons, 24 men and 64 women [mean age 45.7 (SD 8.6) years]. Their level of education was mainly college or university (86\%), and they had spent an average of 13 years in their current workplace.

The criterion for inclusion in this study was physically light work. The volunteers' state of health was assessed in collaboration with an occupational health physician, and it was based on the answers given to the work ability questionnaire and the rating of the intensity of pain or discomfort experienced during the past 7 days. Telephone contact $(\mathrm{N}=28)$ was used to confirm the time of an accident, possible degree of disability, and the factors underlying pain or discomfort [Borg CR10 scale $\geq 5$ (11)]. Two volunteers were advised to contact their physician personally. None of the subjects met the exclusion criteria, which were as follows: difficult or neglected disease, acute injury, postoperative state, inflammation, or neurological signs.

Details on the subjects' musculoskeletal symptoms, psychosocial functioning, and work ability at the time of the baseline measurement have been published previously (12). For both genders the prerequisites of psychosocial functioning were similar to those found earlier in a large sample of Finnish employees $(13,14)$. The musculoskeletal symptoms, as well as the physical functioning and work ability variables, corresponded with the average levels found in previous studies among participants matched for occupation, gender, and age (1518). No gender difference was found for the work ability index, but compared with the older subjects $(\geq 46$ years) the younger subjects ( $\leq 45$ years) had a better $(\mathrm{P}=0.000)$ work ability (index 43 versus 39$)$ (12). Their prognosis of their own work ability after 2 years was also better $(\mathrm{P}=0.004)$ than that of their older counterparts. Further information about the work ability index is presented in table 1. For the hand-grip strength of both genders (19) and the intensity of leisure-time activity of the men, the results were somewhat above average (20).

\section{Measurements}

The independent physical variables were percentage of body fat, spine forward flexion, hand grip strength, aerobic capacity, intensity of musculoskeletal symptoms, musculoskeletal disability and time-weighted intensity of leisure-time activity. Body fat was measured using bioelectrical impedance with the manufacturer's 
Table 1. Work ability index of the office workers $(\mathrm{N}=88)$.

\begin{tabular}{|c|c|c|c|}
\hline Item & Scale & Explanation & $\begin{array}{l}\text { Median } \\
(\mathrm{N}=88)\end{array}$ \\
\hline $\begin{array}{l}\text { Subjective estimation of present work ability compared with the } \\
\text { lifetime best }\end{array}$ & $0-10$ & $0=$ very poor, $10=$ very good & 9 \\
\hline Subjective work ability in relation to physical demands of the work & $1-5$ & $1=$ very poor, $5=$ very good & 4 \\
\hline Subjective work ability in relation to mental demands of the work & $1-5$ & $1=$ very poor, $5=$ very good & 4 \\
\hline Number of diagnosed diseases & $1-7$ & $\begin{array}{l}1=5 \text { or more diseases, } 2=4 \text { diseases, } \\
3=3 \text { diseases, } 4=2 \text { diseases, } \\
5=1 \text { disease, } 7=\text { no diseases }\end{array}$ & 5 \\
\hline Subjective estimation of work impairment due to diseases & $1-6$ & $1=$ full impairment, $6=$ no impairment & 5.5 \\
\hline Sickness absence during past year & $1-5$ & $\begin{array}{l}1=\geq 100 \text { days, } 2=25-99 \text { days, } \\
3=10-24 \text { days, } 4=1-9 \text { days, } 5=0 \text { days }\end{array}$ & 4 \\
\hline Own prognosis of work ability after two years $\left({ }^{a}\right)$ & $1,4,7$ & $\begin{array}{l}1=\text { hardly able to work, } 4=\text { not sure, } \\
7=\text { fairly sure }\end{array}$ & 7 \\
\hline $\begin{array}{l}\text { Psychological resources (enjoying daily tasks, activity and life spirit, } \\
\text { optimistic about the future) }\end{array}$ & $0-4$ & 1 = very poor, 4 = very good & 3 \\
\hline Work ability index ( $\leq 45$ years / $\geq 46$ years ) & $7-49$ & $\begin{array}{l}7-27=\text { poor, } 28-38=\text { moderate, } \\
37-43=\text { good, } 44-49=\text { excellent }\end{array}$ & $43 / 40$ \\
\hline
\end{tabular}

a There was a statistically significant difference between the $\leq 45$-year and $\geq 46$-year age groups, but the median was the same.

equations (Spectrum II, RJL Systems, Detroit, Michigan, USA) (21), spine forward flexion was measured with a myringoniometer $(22,23)$, hand grip strength was measured in the sitting position with an anatomically adjusted strength gauge $(19,24)$, and aerobic capacity was measured by a "nonexercise" test (25). Musculoskeletal pain or discomfort experienced during the previous 7 days was measured on the Borg CR10 scale (11). Restrictions on participation in daily activities (0-4) because of musculoskeletal symptoms experienced during the last 12 months were measured with a modified version of the standardized Nordic questionnaire $(26,27)$. Musculoskeletal pain or discomfort and restriction on participation in daily activities was assessed for 10 different anatomical areas, and two sum indices were formed, which we labeled intensity of musculoskeletal symptoms and disability, respectively. Physical activity was measured by the 1-month all-time recall questionnaire and converted to MET (metabolic equivalent) values by a specific computer program (MetPro $\left.{ }^{\circledR}\right)(28,29)$. The time-weighted intensity of leisuretime activitywas used, as significant age and gender differences in leisure-time activity were found in this study population.

The independent psychological variables were selfconfidence, anxiety, somatic symptoms, and mood. Somatic symptoms and mood were assessed in relation to work and leisure time. The independent variables related to the social environment at work were mental stress at work and the work atmosphere. One-year recall of psychological functioning and the social environment at work was measured by descriptive visual rating scales $(13,14)$. On the scale, 0 represented the worst and 100 the best possible situation. In this study we used the la- bel psychosocial variables to refer to the variables of both the psychological and social environment at work.

The dependent variables were work ability and general subjective well-being. Work ability was measured by the work ability index $(18,30)$. The work ability index consisted of assessments of the physical and mental demands of the individual's work, diagnosed diseases, effect of diseases on work ability, sick leave, work ability prognosis, and psychological resources. General subjective well-being was defined according to life satisfaction and meaning of life (average), which were measured by descriptive visual rating scales $(13,14)$. The hypothetical model and variables used in this study are described in figure 1.

\section{Consistency of measurements}

Intraclass correlation coefficients (ICC) were used to calculate consistency. Measurements conducted among a similar sedentary occupational population $(\mathrm{N}=14-16$, unpublished study) matched the results of previous studies. The questionnaire test-retest ICC values ranged between 0.61 and 0.95 , and the intraobserver consistency fell between 0.75 and 0.97 (table 2). The test-retest percentage of agreement for the modified standardized Nordic questionnaire was $73-93 \%$.

\section{Statistical analyses}

The statistical analyses were carried out by SPSS 9.0. (31). Path analyses were carried out using the PRELIS 2.30 and LISREL 8.30 programs (32).

The path analysis was performed as follows: first, the physical prerequisites of functioning were inserted 


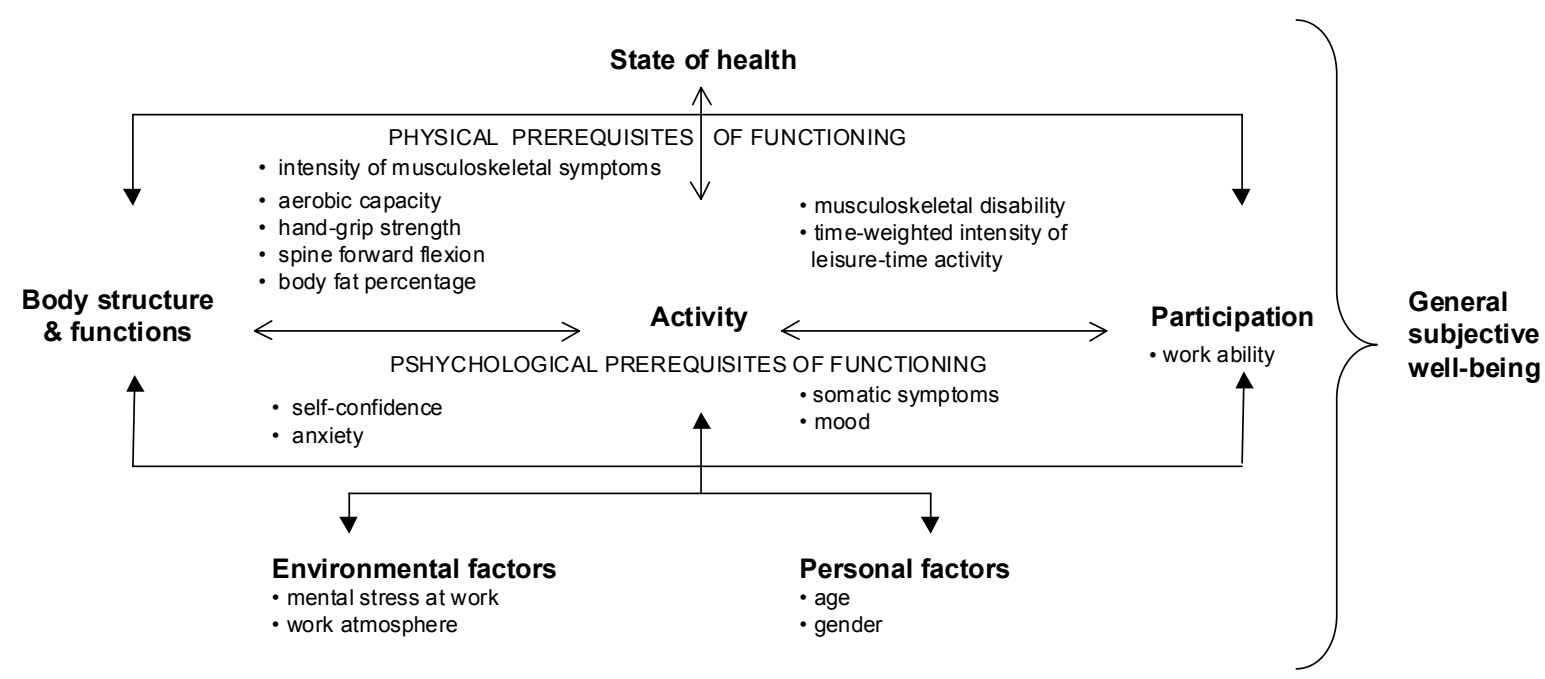

Figure 1. Interactions between the components of the modified version of the International Classification of Functioning, Disability and Health (3) and the hypothetical model and variables used in this study.

Table 2. Consistency of the questionnaires and measurements $(\mathrm{N}=14-16)$ assessed twice within a week, measured by the intraclass correlation coefficient (ICC).

\begin{tabular}{ll}
\hline Measure & ICC \\
\hline Spine forward flexion, intraobserver & 0.75 \\
Hand grip strength, intraobserver & $0.95-0.97$ \\
Aerobic capacity, "nonexercise" test & 0.95 \\
Time weighted intensity of leisure-time activity (METs) & 0.62 \\
Psychological functions, descriptive visual rating scales & $0.61-0.85$ \\
Environmental factors, descriptive visual rating scales & $0.79-0.92$ \\
Work ability index & 0.94 \\
General subjective well-being & $0.87-0.95$ \\
\hline
\end{tabular}

into the model as independent variables, second, the psychological prerequisites of functioning and the variables for social environment at work were added. Third, age and gender were included in the adjustment analysis as independent variables in both final models.

\section{Results}

Association between the variables for physical prerequisites of functioning and work ability and general subjective well-being

The variables for physical prerequisites of functioning, which were related to a good score on the work ability index, were low intensity of musculoskeletal symptoms, good flexibility in spine forward flexion, and good aerobic capacity. These independent variables indirectly affected general subjective well-being through work

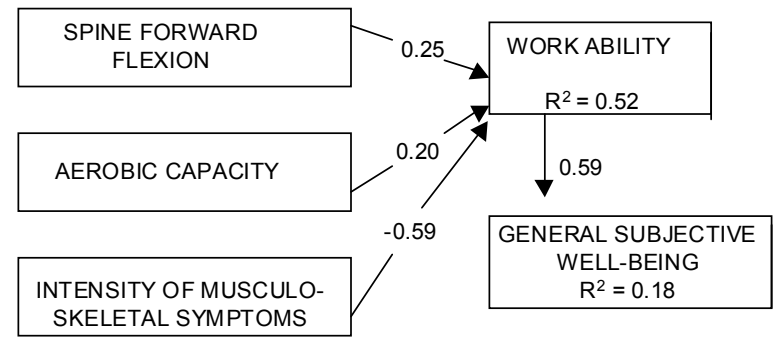

Chi-square $=0.71, \mathrm{df}=3, \mathrm{P}$-value $=0.87$

Figure 2. Variables used for physical prerequisites of functioning in association with work ability and general subjective well-being among office workers $(\mathrm{N}=88)$.

ability, and work ability directly affected general subjective well-being. This model explained $52 \%$ of work ability and $18 \%$ of general subjective well-being (figure 2).

In the adjustment analysis, when we added age and gender as independent variables into the final model, gender was not significant. Age displaced aerobic capacity and spine forward flexion as a predictor of work ability. Age and intensity of musculoskeletal symptoms explained $51 \%$ of work ability, and this model explained $18 \%$ of general subjective well-being. The intensity of musculoskeletal symptoms and age had a negative effect on work ability.

\section{Associations between the variables for physical and psychosocial prerequisites of functioning and work ability and general subjective well-being}

The variables for the physical and psychosocial prerequisites of functioning that were related directly to work 


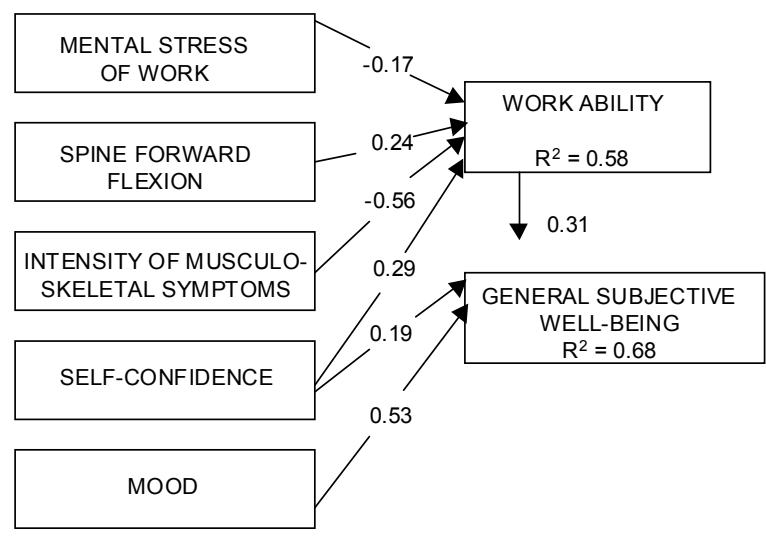

Chi-square $=2.33, \mathrm{df}=4, \mathrm{P}$-value $=0.68$

Figure 3. Variables used for physical and psychosocial prerequisites of functioning in association with work ability and general subjective well-being among office workers $(\mathrm{N}=88)$.

ability were high self-confidence, low mental stress at work, good spine forward flexion, and low intensity of musculoskeletal symptoms. These independent variables had indirect effects on general subjective well-being through work ability. Good mood, self-confidence, and work ability affected general subjective well-being directly. This model explained 58\% of work ability and $68 \%$ of general subjective well-being (figure 3).

In the adjustment analysis, when we added age and gender as independent variables in the final model, gender was not significant. Age displaced spine forward flexion and mental stress at work as a predictor of work ability. Mood, self-confidence, and work ability had direct and unchanging effects on general subjective wellbeing. Age, intensity of musculoskeletal symptoms, and self-confidence explained $58 \%$ of work ability, and the whole model explained $68 \%$ of general subjective wellbeing.

\section{Discussion}

Measuring work ability and subjective well-being is a complex task. Work ability assessments need to be based on both objective findings and workers' subjective evaluations of their resources in relation to work and life demands. In this study we used a work ability index constructed by the Finnish Institute of Occupational Health. The validity of the work ability index has been examined in previous Finnish studies. The index was shown to have associations with health (33), and a poor work ability index was a good predictor of work disability (7, 34). In our study subjective well-being consisted of two general questions on life satisfaction and meaning of life. The assessments were not directed towards specif- ic areas as they are in studies of social indicators or in satisfaction, emotional, or good life approaches (35-38). In this study the participants were free to emphasize whatever aspects of life they wished.

We limited ourselves in this study to examining social environmental factors related to work and ignored nonwork-related social factors. We also did not analyze factors related to the physical work environment, as the work done across the group was very similar, consisting of physically light, mostly computer-based mental work. Of course, personal work styles and routines can vary considerably, and such a variation may have had some influence on our results.

In this study the consistency of the measurements varied between high and fair ( $>0.80$ high, $0.80-0.61$ fair, and $0.60-0.40$ poor) on the intraclass correlation scale (39). The consistency of the measurements related to the physical prerequisites of functioning and work ability variables was similar to that reported in previous studies $(17,29,40,41)$. The consistency of the measurements of the psychological prerequisites of functioning and general subjective well-being was slightly better than that obtained in previous studies $(13,14)$. There were no previous consistency measures for the "mental stress at work" or "work atmosphere" questions.

Of this office worker population, $72.4 \%$ participated in both the physical examination and the self-administered questionnaires $(58.5 \%$ of the men and $79.3 \%$ of women). The rate of participation was higher among the women $(\mathrm{P}=0.019)$. There were no other differences in the personal factors (eg, in age or education) between those who volunteered to take part in the experimental rehabilitation study and those who refused to participate. In the physical and work ability measurements the only difference was in aerobic capacity, which was reported as slightly better among those who refused to participate $(\mathrm{N}=21)(\mathrm{P}=0.012)$. Because the sample was small $(\mathrm{N}=88)$, the results can be considered to be tentative only.

High intensity of musculoskeletal symptoms and age had the greatest negative effect on work ability. The individual components of the physical function variables (intensity of musculoskeletal symptoms, spine forward flexion, and aerobic capacity) explained $52 \%$ of the work ability index. When we added the psychosocial variables to the model, the degree of explanation increased slightly to 58\%. Self-confidence and mental stress at work emerged as significant, together with the intensity of musculoskeletal symptoms and spine forward flexion. Self-confidence is one of the components of the psychological function variables, and mental stress at work is a component of the variable for social environment at work. Stress at work included responsibility at work, work tempo, and mental stress at work. When age and gender were incorporated into the 
models with the use of the adjustment analysis, the explanatory powers of work ability did not increase because age displaced the independent variables. If work ability is to be maintained and the effectiveness of rehabilitation is to be improved, it is important to identify all the independent variables, in addition to age and gender, that can have effects in the workplace.

Only $18 \%$ of general subjective well-being was explained by the variables for physical prerequisites of functioning and work ability. This value increased to $68 \%$ when the psychosocial variables were entered into the model. Self-confidence ("functions" component), mood ("activity" component) and work ability ("participation" component) affected general subjective wellbeing directly. According to the simultaneous model path analysis, work ability explained general subjective well-being better than vice versa. To the best of our knowledge, this is the first time the interactions between the physical and psychosocial prerequisites of functioning, work ability, and general subjective well-being have been studied in the framework of a modified version of the International Classification of Functioning, Disability and Health.

In our study, the results obtained with the work ability index were primarily in agreement with those of previous epidemiologic studies of municipal workers. Musculoskeletal and psychological symptoms $(5,6)$ and age $(3,6)$ had a negative effect on the work ability index, and the social environment at work has been shown to be important in terms of factors such as freedom, recognition, esteem at work, division of labor, and supervisor's attitude (3-6). Leisure-time physical activity has previously been associated with the work ability index $(3,4)$, but it was not in either our study or in that by Pohjonen (6). Correlations have been found between the work ability index and both aerobic capacity and muscular strength in previous studies $(7,8)$. Our results differed with respect to muscular strength, as we found no correlations between the latter and the work ability index. Comparing the present study with previous ones is problematic when one allows for the differences in study populations and work demands (3-8). No previous studies have been published that explain factors of the work ability index among workers with physically light demands.

It can be concluded that office workers, like manual workers, face challenges of musculoskeletal and mental symptoms in seeking to maintain their work ability and general subjective well-being. The physical prerequisites of functioning are among the most important factors in maintaining work ability. A high intensity of musculoskeletal symptoms had the greatest negative effect on work ability in our study, as it had also in earlier studies. The psychological prerequisites of functioning turned out, however, to be more important in main- taining general subjective well-being. Self-confidence, mood, and work ability directly affected general subjective well-being. Of the environmental factors, mental stress at work had an association with work ability, but its effect was not as significant as that of the physical and psychological prerequisites of functioning. In this study population gender did not play a significant role. When intervention programs to maintain work ability and general subjective well-being are planned, factors that directly and indirectly support these variables should be taken into consideration, particularly for aging workers.

\section{Acknowledgments}

We would like to thank Seija Talo for her advice on to how handle interactions between the components of the modified International Classification of Functioning, Disability and Health. We thank Mr Michael Freeman for checking the language of the manuscript.

\section{References}

1. Ministry of Social Affairs and Health. Trends in social protection 1998-1999. Helsinki: Ministry of Social Affairs and Health,1999. Publications of the Ministry of Social Affairs and Health, no 8. (http://www.vn.fi/stm/english/tao/publicat/ taocontents5.htm)

2. Eriksen H, Svendsrod R, Ursin G, Ursin H. Prevalence of subjective health complaints in the Nordic European countries 1993. Eur J Public Health 1999;8:294-8.

3. Tuomi K, Luostarinen T, Ilmarinen J, Klockars M. Work load and individual factors affecting work disability among aging municipal employees. Scand J Work Environ Health 1991;17 suppl 1:94-8.

4. Tuomi K, Ilmarinen J, Martikainen R, Aalto L, Klockars M. Aging, work, life-style and work ability among Finnish municipal workers in 1981-1992. Scand J Work Environ Health 1997;23 suppl 1:58-65.

5. Tuomi K, Eskelinen L, Toikkanen J, Järvinen E, Ilmarinen J, Klockars M. Work load and individual factors affecting work ability among aging municipal employees. Scand J Work Environ Health 1991;17 suppl 1;128-34.

6. Pohjonen T. Perceived work ability of home care workers in relation to individual and work-related factors in different age groups. Occup Med 2001;51(3):209-17.

7. Pohjonen T. Age-related physical fitness and the predictive values of fitness tests for work ability in home care work. J Occup Environ Med 2001;43(8):723-30.

8. Nygård C-H, Eskelinen L, Suvanto S, Tuomi K, Ilmarinen J. Associations between functional capacity and work ability among elderly municipal employees. Scand J Work Environ Health 1991;17 suppl 1:122-7.

9. Seitsamo J, Ilmarinen J. Life-style, aging and work ability among active Finnish workers in 1981-1992. Scand J Work Environ Health 1997;23 suppl 1:20-6. 
10. World Health Organization (WHO). ICF/ICIDH-2: international classification of functioning, disability and health: final draft, full version: classification, assessment, surveys, and terminology team. Geneva: WHO, 2001. (http:/ www.who.int/icidh)

11. Borg G. Borg's perceived exertion and pain scales. Champaign (IL): Human Kinetics, 1998.

12. Sjögren-Rönkä T, Ojanen M, Mustalampi S, Mälkiä E. Musculoskeletal symptoms and psychosocial functioning by gender and age on subjects with sedentary occupation. In: $\mathrm{Ny}$ gård $\mathrm{C}-\mathrm{H}$, Luopajärvi T, Lusa S, Leppänen M, editors. Promotion of health through ergonomic working and living conditions: proceeding 33rd Annual Congress of the Nordic Ergonomics Society; 2001 September 2-5; Tampere (Finland). University of Tampere, School of Public Health, Tampere, 2001:422-6. Publication no 7.

13. Ojanen M. Liikunta ja psyykkinen hyvinvointi [Physical exercise and psychological well-being]. Helsinki: Liikuntatieteellinen seura, 1994. Liikuntatieteellisen seuran moniste 19.

14. Ojanen M. Effects of illness and adversity on quality of life. In: Jobin J, Maltais F, LeBlanc P, Simard C, editors. Advances in cardiopulmonary rehabilitation. Champaign (IL): Human Kinetics Press, 2000:198-210.

15. Piirainen H, Elo A-L, Hirvonen M, Kauppinen K, Ketola R, Laitinen $\mathrm{H}$, et al. Terveydentila ja työkyky [State of health and work ability]. In: Piirainen H. Terveydentila ja työkyky: työ ja terveyshaastattelututkimus v. 2000 [Work and health — interview study year 2000]. Helsinki: Työterveyslaitos, 2000:21-22. Taulukkoraportti.

16. Shvartz E, Reibold RC. Aerobic fitness norms for males and females aged 6 to 75 years: a review. Aviat Space Environ Med 1990;61:3-11.

17. Mellin G. Development and assessment of noninvasive methods for spinal mobility measurements and their correlations with the degree of low back pain, 1988. Helsinki: Kuntoutussäätiö, 1988. Research reports, no 22.

18. Ilmarinen J, Tuomi K, Klockars M. Changes in the work ability of active employees over an 11-year period. Scand J Work Environ Health 1997;23 suppl 1:49-57.

19. Mathiowetz V. Grip and pinch strength measurements. In: Amundsen LR, editor. Muscle strength testing: instrumented and non-instrumented systems. New York (NY): Churchill Livingstone, 1990:163-76.

20. Mälkiä E, Impivaara O, Maatela J, Aromaa A, Heliövaara M, Knekt P. Suomalaisten aikuisten fyysinen aktiivisuus [Physical activity of Finnish adults]. Turku (Finland): Kansaneläkelaitos, 1988. Kansaneläkelaitoksen julkaisuja ML: 80 . English abstract.

21. Sipilä S, Multanen J, Kallinen M, Era P, Suominen H. Effects of strength and endurance training on isometric muscle strength and walking speed in elderly women. Acta Physiol Scand 1996;156:457-64.

22. Mellin G. Measurement of thoracolumbar posture and mobility using a Myrin inclinometer. Spine 1986:11;759-62.

23. Mellin G. Method and instrument for noninvasive measurements of thoracolumbar rotation. Spine 1987;12:28-31.

24. Mälkiä E. Muscular performance as a determinant of physical ability in Finnish adult population [English abstract]. Turku (Finland): Social Insurance Institution, 1983. Publications of the Social Insurance Institution of Finland, AL: 23.

25. Jackson AS, Blair SN, Mahar MT, Wier LT, Ross RM, Stuteville JE. Prediction of functional aerobic capacity without exercise testing. Med Sci Sports Exerc 1990;22:863-70.
26. Andersson K, Karlehagen S, Jonsson B. The importance of variations in questionnaire administration. Appl Ergon 1987;18(3):229-32.

27. Kuorinka I, Jonsson B, Kilbom A, Vinterberg H, BieringSørensen F, Andersson G, et al. Standardised Nordic questionnaires for the analysis of musculoskeletal symptoms. Appl Ergon 1987;18.3:223-37.

28. Mälkiä E, Impivaara O, Heliövaara M, Maatela J. The physical activity of healthy and chronically ill adults in Finland at work, at leisure and during commuting. Scand J Med Sci Sports 1994:4;82-7.

29. Mälkiä E. MET based questionnaire for the study of physical activity. In: Mälkiä E, Sihvonen S, editors. Assessment of function and movement: selected papers : Third Nordic Symposium on Physiotherapy. Jyväskylä (Finland): PainoPorras Oy, 1996:92-103.

30. Tuomi K, Ilmarinen J, Eskelinen L, Järvinen E, Toikkanen J, Klockars M. Prevalence and incidence rates of diseases and work ability in different work categories of municipal occupations. Scand J Work Environ Health 1991;17 suppl 1:67-74.

31. SPSS Inc. 9.0 Base user's guide. Chicago (IL): Marketing Department SPSS Inc, 1999.

32. Jöreskog K, Sörbom D, du Toit S, du Toit M. LISREL 8. Chicago (IL): Scientific Software International Inc, 1999.

33. Eskelinen L, Kohvakka A, Merisalo T, Hurri H, Wägar G. Relationship between the self-assessment and clinical assessment of health status and work ability. Scand J Work Environ Health 1991;17 suppl 1:40-7.

34. Tuomi K, Toikkanen J, Eskelinen L, Backman A-L, Ilmarinen J, Järvinen E, et al. Mortality, disability and changes in occupation among aging municipal employees. Scand J Work Environ Health 1991;17 suppl 1:58-66.

35. Dijkers M. Measuring quality of life. In: Fuhrer MJ, editor. Assessing medical rehabilitation practices: the promise of outcomes research. Baltimore (MD): Paul H Brookes Publishing Co, 1999:153-179.

36. Frisch MB. Quality of life therapy and assessment in health care. Clin Psychol Sci Pract 1998;5:19-40.

37. Argyle M. Causes and correlates of happiness. In: Kahneman D, Diener E, Schwartz N, editors. Foundations of hedonic psychology. New York (NY): Russell Sage Foundation, 1999:353-73.

38. Robbins SB, Kliewer WL. Advances in theory and research on subjective well-being. In: Brown SD, Lent RW, editors. Handbook of counseling psychology. 3rd ed. New York (NY): Wiley, 2000:310-45.

39. Baumgartner TA. Norm-referenced measurement: reliability. In: Safrit MJ, Wood TM, editors. Measurement concepts in physical education and exercise. Champaign (IL): Human Kinetics Press, 1989:62-65.

40. Kemmlert K, Kilbom Å. Besvär i nacke/skuldra och samband med arbetssituation: en utvärdering med hjälp av frågeformulär och arbetsplatsbesök [Connection between neck and shoulder symptoms in work situations]. Stockholm: Arbetslivsinstitutet, 1988:17. Arbete och hälsa, no 17. English abstract.

41. Rasku A, Ruoppila I, Feldt T. Esimiesten työkyky: yksilölliset ja työhön liittyvät tekijät työkyvyn selittäjinä yli 55-vuotiailla esimiehillä [Supervisors' work ability: individual and work-related factors as explanatory variables in the work ability of supervisor aged 55+]. Gerontologia 1999;13(1):13-21.

Received for publication: 24 January 2001 